\title{
TOWARDS MULTILATERAL CO-OPERATION OF UNIVERSITY, ICT-BUSINESSES AND PUBLIC ORGANIZATIONS IN THE ROVANIEMI REGION
}

\author{
Developing Network Competence
}

Mika Saloheimo, Miina Konttinen, Ilkka Kamaja and Juha Lindfors

University of Lapland, Department of Research Methodology

\begin{abstract}
The Network Competence (NetCom) project consists of a master's degree programme as well as education and development services for its corporate partners. The goals of the project are to develop regional ICT industries in cooperation with University of Lapland and other public organizations. ICT education and research should be based on the long-term needs of the industry. The project is currently surveying the needs of its corporate partners, and the implications of the findings for training and development are being considered in the project's feedback and evaluation processes.
\end{abstract}

Key words: industry training, organizations, partnerships, educational management

\section{INTRODUCTION}

The Rovaniemi region consists of the City of Rovaniemi and its surrounding municipalities. The city is the capital of Finland's northernmost province, Lapland and is an international centre of business, administration and education. The leading industries in the region are tourism, information and communications technology (ICT), cold and winter technology, special foods and wood products.

The University of Lapland was founded in 1979. While it is a comparatively small institution, with an enrolment of 3500 students, it is an important regional actor. The University has four faculties - Law, Education, Social Sciences and Art and Design. Information Technology 
(IT) has been taught in the Department of Research Methodology since 1997. The subject cannot be studied as a major at the University and the master's programmes described below have been established as a solution to this shortcoming. The first master's programme (ITMO) was started in 2000 and the second (NetCom) in 2002. The basic idea of the programmes is that students complete a major $(82.5 \mathrm{cr})$ in one of the faculties and take studies $(82.5 \mathrm{cr})$ equivalent to a major in IT. The resulting programme, in particular the master's thesis, is cross-disciplinary, focusing on IT applications in the subjects taught in the faculties. Figure 1 illustrates the cross-disciplinary studies in IT.

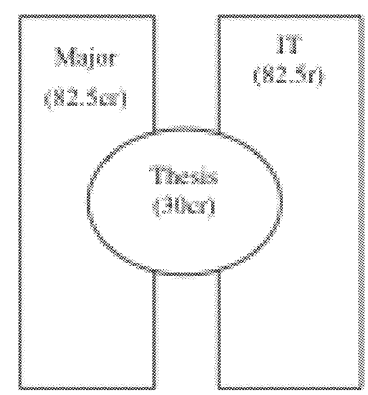

Figure 1. Degree structure of the IT master's programmes.

In the following sections, we describe the goals, background research, organization and future vision of the Network Competence project.

\section{GOALS OF THE NETWORK COMPETENCE PROJECT}

The ICT sector is considered strategically important in the Rovaniemi region, and there is growing need for people with know-how in the field (ICT sector strategy for the Rovaniemi region, 2-3). One aim of the NetCom project is to further the development of the ICT industry and the businesses that are heavily reliant on information technology. The goal of the education, research and collaborative projects supported by the project is to provide opportunities for organizations, businesses and individuals to develop and broaden their IT know-how significantly.

An assessment of university master's programmes by the Ministry of Education has indicated that although many of the master's programmes at the University of Lapland emphasise entrepreneurship, their links to business 
life rely largely on the personal contacts of the individuals involved (Raivola et al., 2002, p77). One of the express objectives of the University's adult education strategy is the promotion of interaction between the University and working life. (see University of Lapland 2010 Strategy). Here, NetCom has set itself the goal of long-term, broad-based cooperation between the University and the business sector in Lapland. This will take the form of cooperation between the IT programme at the Department of Research Methodology and ICT sector businesses in the Rovaniemi region.

One of NetCom's principal goals is to apply a client-centred model to the planning, implementation and evaluation of the education it offers. Such an approach would enable research and education to better address the needs of the public sector and business life. Client-centeredness in the planning and implementation of IT training means working to take into account the expectations and needs of the target group and/or the demands of working life with regard to IT skills.

\section{SURVEY OF CORPORATE PARTNERS}

In August 2002, the Department of Research Methodology began conducting a survey to obtain background information that would facilitate implementation of the NetCom project. The results of the survey will be used in planning the master's programme and client-centred staff training that is tailored to client needs; the findings will also stimulate ideas for development projects and other projects. The survey encompasses the needs of businesses with regard to know-how, training and cooperation. The focal interests are: a profile of staff know-how in the target businesses, the training available to the staff, and the needs for development in these areas; the need for projects, research and development efforts; and the role of the university in serving businesses and the region.

The businesses surveyed comprise the ICT sector businesses in the Rovaniemi region as well as businesses that make extensive use of ICT. A number of public-sector organizations have also been included. For the most part, the persons taking part in the survey are members of staff who are responsible for staff training and development. Requests for participation in the survey have been sent to 17 organizations or businesses, of which 12 have taken part to date, most of these ICT businesses. The 12 include the principal ICT businesses in the region.

The survey data have been collected using interviews and pre-interview tasks. Interviews are semi-structured and are conducted as individual or pair interviews. In the tasks, the businesses are asked to plan a programme of training that suits their needs based on the courses currently offered in the 
Department of Research Methodology. They also have the option of including courses from fields other than IT.

The survey is in progress and the target group is growing. Preliminary findings are available and these are presented in what follows:

Expertise needs. ICT businesses are increasingly required to have theoretical expertise as well as practical skills. The demands made of staff have expanded and deepened, and a strictly technological orientation to one's work is not longer sufficient. The know-how presently required lies in the areas of planning, development, project management, problem solving and general management. Businesses need a diverse range of experts who have the ability to adapt to changes, an understanding of the social dimension of their work, and a desire to develop themselves.

Educational needs. The businesses need both university-level, degreeoriented courses and short-term expert training. The courses offered at the University should be multidisciplinary in nature, i.e., ones in which it is possible to combine ICT and other professional fields. The businesses involved would like some input into the ICT training provided, in particular the curricula. Other priorities noted include the quality of training and research and the fit between training and working life.

Project, research and development needs. All of the business surveyed displayed an interest in project, research and development work that would be carried out in collaboration with the University. This work has to be sufficiently broad in scope and should serve the interests of not only the businesses involved but also the Department of Research Methodology. Many of the business have experiences of such cooperation with various educational organizations.

Role of the University in serving businesses and the region. The University of Lapland should increase cooperation with businesses and organisations in the surrounding community. In order to function smoothly and develop, the ICT sector needs an infrastructure that includes both highlevel research and a qualified workforce. With a view to ensuring that these aims are met, the businesses suggested that the education in IT offered at the University of Lapland should be developed into a degree programme. Among other things, this would make it possible to implement the bachelor's-to-master's bridge programme that they consider necessary. The businesses regard NetCom as a sound foundation for developing cooperation between the Department of Research Methodology and the business community as well as for furthering teaching and research in IT.

Further discussions with the corporate partners (see following section) have provided a more detailed view of the training needs. There is a need for training in the field of information technology, e.g., in software architectures, methods of software production, mobile applications and 
information security. Furthermore, there are needs in fields other than information technology, e.g., management, business know-how and the use of IT in different organizations and businesses.

\section{ORGANIZATION OF THE NETWORK COMPETENCE PROJECT}

The Network Competence project is financed both publicly and privately. Public funding comes from the European Social Fund and the municipalities of the Rovaniemi region. Private funding comes from NetCom's corporate partners.

The organizations involved in NetCom are the State Provincial Office of Lapland and Business Developer eero Rovaniemi. The project's corporate partners are: CCC Systems Ltd., GeraCap Ltd., LapIT Ltd., Saraware Ltd. and Sonera Plc. Two of the corporate partners are SMEs. The organization of NetCom is presented in Figure 2.

GeraCap designs software and communication technologies. Saraware designs real-time communication systems. CCC Systems supplies customised information systems. LapIT produces network services, support and training. Sonera is a tele-operator. The operations of the project's corporate partners can be roughly divided into two categories: software production and network services/technologies.

Business developer eero Rovaniemi facilitates and develops informationintensive business activities as well as coordinates different projects and the marketing of the region. Closely linked to eero is the Aurora Borealis Technology Center (AB), whose goals include the creation of a testing platform for wireless services in the field of travel and tourism (navigation, experiences, etc.) Applications for distance health care and leisure are also under consideration as part of the Center's Testing Lab (TL).

The University of Lapland and its Department of Research Methodology are the executive and coordinating organization for NetCom. The role of the project's corporate partners and eero is that of advisor and funding organization. The State Provincial Office is the legal supervisor of the project and provides most of the funding.

There are two main policy-making units in NetCom. The Steering Group comprises representatives of the project's different stakeholders; such a body is a common tool for managing European Union (EU) projects. The Group handles administrative tasks and legal supervision, for example, drawing up the annual budget framework. Modifications to the project plan must be accepted by the Group. The Group's working procedures can be described as formal. 
The project's other policy-making unit is the Advisory Board, which has a key role in the NetCom process. All the companies and organizations directly involved in NetCom have membership in the Board. Representation of other organizations (i.e., other units of University of Lapland) is possible where necessary.

The Advisory Board concentrates on questions of substance related to the development of regional ICT business activities. It evaluates different needs, ideas and, naturally, the operation of NetCom. The Board is an important part of the feedback mechanism. It works more informally than the Steering Group and adheres to the rules and restrictions set by the Group.

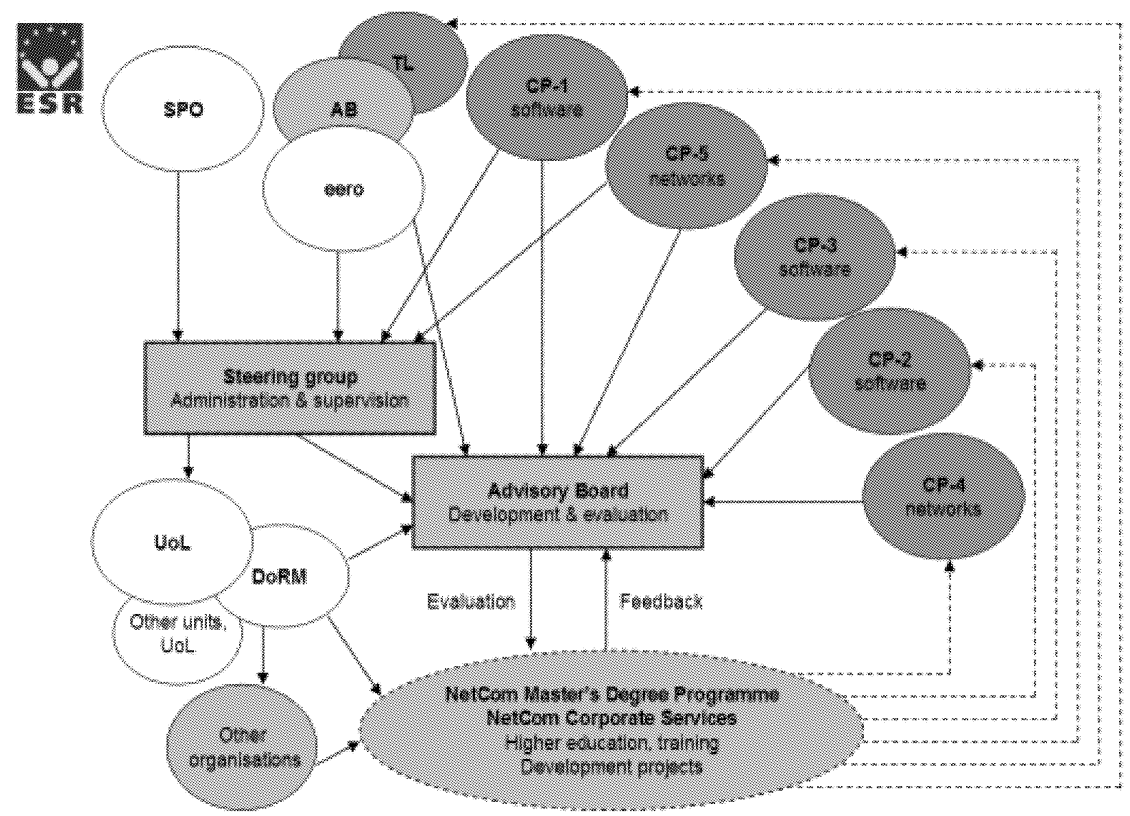

Figure 2. Organization of the Network Competence project. Legend: SPO $=$ State Provincial Office, eero = Business Developer eero Rovaniemi, $\mathrm{AB}=$ Aurora Borealis Technology Center, $\mathrm{TL}=$ Testing Lab, CP-N $=$ Corporate Partner N, UoL = University of Lapland, DoRM = Department of Research Methodology.

In exchange for their investment in NetCom, the corporate partners receive NetCom Corporate Services. Corporate partners are full members of the Advisory Board and influence the long-term (degree-level) education in Information Technology and short-term training of their employees. In this way, the education can be designed with the needs of working life in mind. The Board also participates in the quality management of IT education at the University of Lapland. 
NetCom's master's degree programme provides highly educated potential recruits for its corporate partners. Students in the programme are encouraged to do their thesis and practice projects for the corporate partners. NetCom Corporate Services provides a certain amount of customised training based on the needs of the partners. Partners' employees can also participate in the courses that make up the degree programme. The Board also considers potential development projects. Development can be targeted to a partner's business processes and development projects can involve individual or multiple partners. An important source of these projects is the Aurora Borealis Technology Centre and Testing Lab.

\section{CONCLUSIONS}

The Network Competence project is still in its early stages. The project will end in December 2005. The NetCom master's degree programme started in November 2002 with 17 students, and more students can apply in autumn 2003. There is a clear need for an established cross-disciplinary degree in Information Technology instead of separate degree programmes. This will be linked to the reform of higher educational system in year 2005 . The expertise and educational needs of the project's corporate partners have been surveyed and there will be certain customised short-term training courses starting in autumn 2003.

NetCom's Advisory Board is to be a permanent body for liaising between companies and the University. In the future, there will be a need to expand the Board's membership to include representatives from companies in other industries (i.e., travel and tourism) in addition to ICT. NetCom has already created a functioning network of contacts between local companies and the University.

The Network Competence project has started off well, with the initial problems of defining and organising the NetCom Corporate Services now mainly solved. The services offered are mainly based on present functions of the University, presented and implemented in a client-centred manner. Corporate partners differ somewhat in their needs for services, but there are certain synergies between them.

Customised training for the corporate partners will be provided partly by third parties. The Department of Economic Sciences and Tourism offers many courses that are relevant for the partners (management, marketing and other business-related studies). Some IT-related training will be provided by outside organizations.

Corporate partners have provided valuable feedback for the information technology curriculum at the University of Lapland in which they have 
identified salient concerns. One is how to implement the courses so that they will be easily accessible to the personnel of the corporate partners. Traditional implementation (lectures, exercises and examination) should be rethought.

There will probably be some administrative concerns related to the de minimis regulation, which pertains to public support and funding for companies. Also, the training provided by outside organizations has to be arranged through competitive bidding. On the educational side, there is a need for consulting the local SMEs (other than those in the ICT sector) on how to make use of ICT in their business. One future challenge is to develop research that will support the regional ICT industry (or any regional industry). The research possibilities will be surveyed in autumn 2003. Thus far, no individual corporate partner has indicated detailed needs where research is concerned; rather, it is probable that most of the research needs will emerge from Business Developer eero Rovaniemi and Aurora Borealis Technology Centre.

\section{REFERENCES}

Lapin yliopisto 2010-strategia [online]. (accessed 4.2.2003). Available at http://www.urova.fi/home/suun/strategiat/index.htm.

Raivola, R., Himberg, T., Lappalainen, A., Mustonen, K. \& Varmola, T. (2002). Monta tietä maisteriksi. Yliopistojen maisteriohjelmien arviointi. Korkeakoulujen arviointineuvoston julkaisuja 3:2002. Helsinki: Pikseri julkaisupalvelut. Available at: http://www.kka.fi/pdf/julkaisut/KKA_302.pdf.

Rovaniemen seudun ICT-alan strategia [online]. (accessed 4.2.2003) Available at: http://www.rovaniemi.fi/files/ICT-alan\%20strategia.pdf

\section{BIOGRAPHY}

Mika Saloheimo (mika.saloheimo@urova.fi) is the NetCom-project's Planning Officer. His research interests are in the use of ICT in business processes. Miina Konttinen (mina.konttinen@urova.fi) is the project's Educational Planning Officer and is writing her master's thesis on the competence needs of the ICT businesses in the Rovaniemi region. Ilkka Kamaja (ilkka.kamaja@urova.fi) is the development manager and is working on a doctoral dissertation dealing with a client-centred educational planning model. Juha Lindfors (juha.lindfors@urova.fi) is professor in ICT and his research interests are in learning environments. His thesis dealt with modern learning environments for Control Engineering. 